\title{
Experimental study of the influence of thawing permafrost on the chemical properties of sea water
}

\author{
M. Pogojeva ${ }^{1,2}$, E. Yakushev ${ }^{2,3}$, A. Ilinskaya ${ }^{2,4}$, A. Polukhin ${ }^{2}$, H.-F. Braaten ${ }^{3}$, and T. Kristiansen ${ }^{3}$
}

Received 29 Marh 2018; accepted 6 August 2018; published 26 September 2018.

In a warming environment, permafrost thawing can play a significant role in the chemical composition of coastal waters in the Arctic region. It is a potential source of organic and inorganic forms of nutrients, as well as heavy metals and pollutants. To estimate the permafrost thawing influence on the chemical properties of the sea water, an experimental study was conducted as part of a Norwegian-Russian expedition to Svalbard 11-17 June 2017. Permafrost (PF) samples were collected at an abrasive cliff $10 \mathrm{~km}$ west of Longyearbyen, after that, the experiment was performed at the University of Svalbard laboratory. The experiment was focused on identifying the possible changes in concentrations of nutrients, carbonate system parameters, and pollutant composition related to permafrost thawing. During the experiment, the samples of permafrost were added to the seawater. Then, the solution was exposed to natural conditions outdoors for 24 hours while water samples from the solution were taken at specified time intervals. Data from the experiment allowed for estimating the rate and change in concentrations of chemical substances due to permafrost thawing. This study shows the importance of permafrost thawing in the coastal areas chemical regime, affecting the metals supply, ocean acidification, and nutrient inputs; therefore, coastal ecosystems could be exposed to new impacts of numerous stresses associated with global warming. KEYWORDS: Permafrost thawing; sea water biogeochemistry; acidification; pollution.

Citation: Pogojeva, M., E. Yakushev, A. Ilinskaya, A. Polukhin, H.-F. Braaten, and T. Kristiansen (2018), Experimental study of the influence of thawing permafrost on the chemical properties of sea water, Russ. J. Earth. Sci., 18, ES5002, doi:10.2205/2018ES000629.

\section{Introduction}

The Arctic Ocean is different from all other oceans because of the large drainage area with ter-

\footnotetext{
${ }^{1}$ State Oceanographic Institute, Moscow, Russia

${ }^{2}$ Shirshov Institute of Oceanology RAS, Moscow, Russia

${ }^{3}$ Norwegian Institute for Water Research, Oslo, Norway

${ }^{4}$ Norwegian University of Science and Technology, Trondheim, Norway

Copyright 2018 by the Geophysical Center RAS. http://rjes.wdcb.ru/doi/2018ES000629-res.html
}

restrial permafrost, and presence of the subsea permafrost. Large terrestrial parts as well as seabed associated with Siberia, Alaska, and Svalbard are covered by permafrost. Global warming over the last few decades has led to a rise of temperature in the Arctic, which has greatly reduced the distribution and thickness of the sea ice and more open seas are exposed to incoming sunlight and heat [IPCC, 2014]. The warming of the sea water and the reduction in the sea ice will lead to a permafrost thawing and erosion along the coast, previously protected by the sea ice [AMAP, 2017]. When permafrost melts and the erosion of the coast occurs, a large amount of methane, carbon dioxide, 


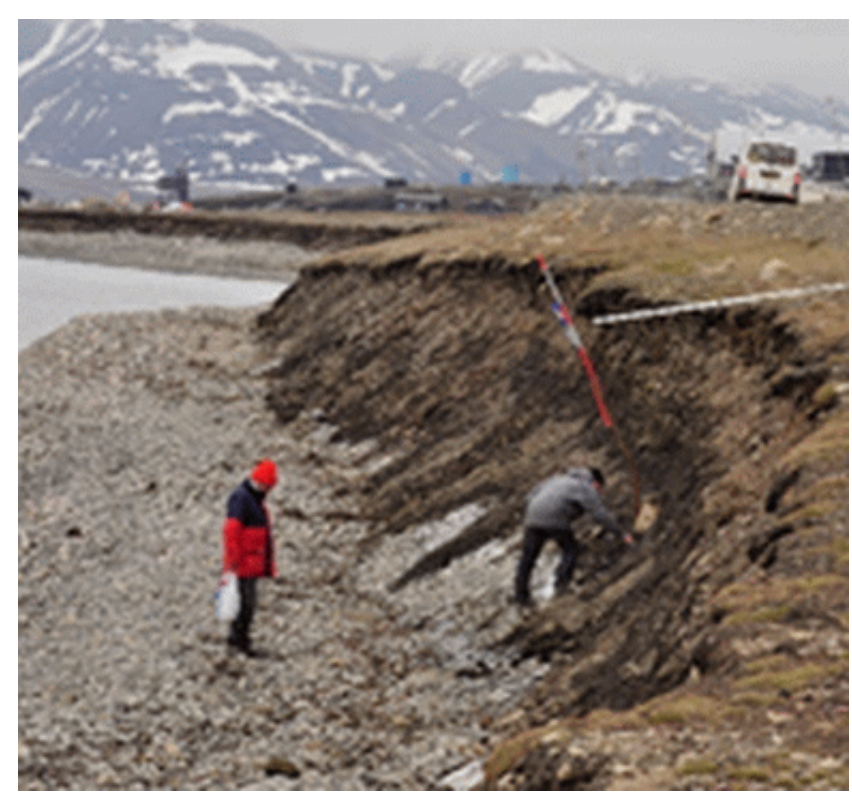

Figure 1. Abrasive cliff in Svalbard.

organic carbon, nutrients, and potential pollutants are released and transported to the atmosphere, rivers, and seas [Semiletov et al., 2013. Vonk et al., 2012 .

There are large knowledge gaps in our understanding of how permafrost thawing changes the properties of the sea water. Projecting the effect of permafrost into the future climate is not straightforward and today's climate models do not include carbon emissions into the ocean and atmosphere via permafrost thawing. We hypothesise that permafrost thawing can be an important source for certain chemical parameters at least in the coastal Arctic areas. The goal of this work was to conduct an experiment in Svalbard to study the permafrost thawing effect on the sea water properties and to analyse and interpret the results with respect to the chemical effects of permafrost thawing on the Arctic coastal waters.

\section{Materials and Methods}

During the joint Norwegian-Russian expedition to Svalbard 11-17 June 2017, experimental studies of the permafrost thawing effect on the biogeochemical parameters of the seawater were carried out. Samples of permafrost were collected from an abrasive cliff (Figure 1) located about $10 \mathrm{~km}$ west of Longyearbyen, Svalbard.
This "microcosm" experiments were organized as follows. The samples of permafrost, (about 50 $55 \mathrm{~g})$ were added to the 1 liter flasks with seawater (SW). The bottles with open lids were exposed for 24 hours in the air temperature inside plastic boxes covered with lids to simulate the natural conditions. Measurements of the samples were collected after $0,3,6,12$, and 24 hours for exposition for $\mathrm{pH}$, the carbonate system, nutrients, and heavy metals, including mercury and methylmercury. Simultaneously, the measurements in a reference experiment were conducted over 24 hours in seawater without permafrost and distilled water with permafrost (PF, Table 1). The sampling techniques for the measured parameters were organized in accordance with the standard procedures [Grashoff et al., 1999].

Nutrients were sampled in $100 \mathrm{~mL}$ plastic bottles and preserved with sulfuric acid. Samples for Alkalinity (Alk) and Total Inorganic Carbon (TIC) were preserved with mercury chloride. Water samples for $\mathrm{Hg}$ species analysis were collected in $250 \mathrm{~mL}$ fluorinated polyethylene (FLPE) bottles [Braaten et al., 2014. pH was measured immediately af-

Table 1. Exposition period and sampling during the "microcosm" experiment, where PF - permafrost, SW - sea water and DW - distilled water.

\begin{tabular}{|l|l|l|l|l|l|}
\hline Sample & \multicolumn{3}{|l|}{ Exposition period and sampling, } \\
hours & \multicolumn{4}{l|}{} \\
\hline & 0 & 3 & 6 & 12 & 24 \\
\hline SW & & & & & \\
\hline SW+PF 3 & & & & & \\
\hline SW+PF 6 & & & & & \\
\hline SW+PF 12 & & & & & \\
\hline SW+PF 24 & & & & & \\
\hline SW w/o PF & & & & & \\
\hline DW+PF & & & & & \\
\hline
\end{tabular}


(a)

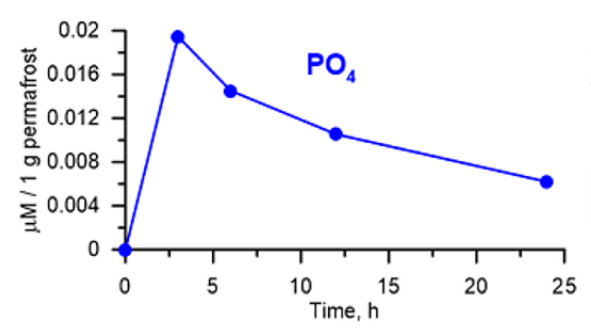

(b)

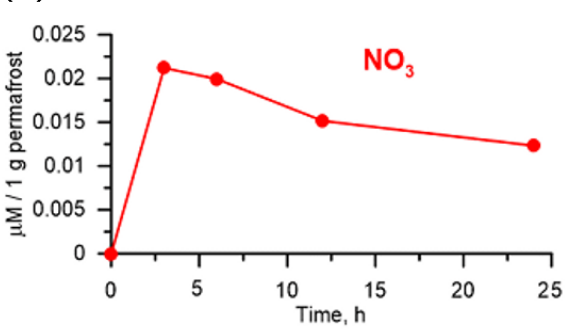

(c)

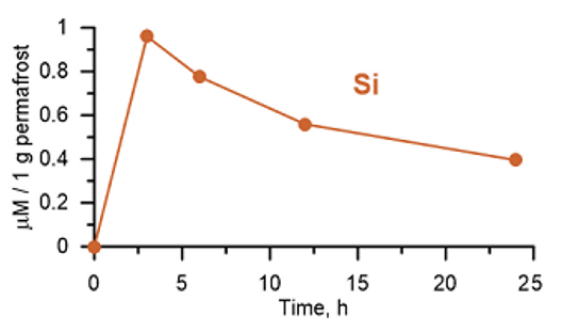

Figure 2. Change in concentrations of phosphate, $\mathrm{PO}_{4}(\mathrm{a})$, nitrate and nitrite, $\mathrm{NO}_{3}(\mathrm{~b})$ and silicate, $\mathrm{Si}$ (c) as a result of thawing $1 \mathrm{~g}$ of permafrost in 1 liter of the sea water.

ter sampling with a $\mathrm{pH}$-meter, and the electrode was calibrated before each measurement. Samples for carbonate system, nutrients,and mercury forms were measured in Norwegian Institute for Water Research (NIVA), Oslo; forms of total metals were measured in Zubov State Oceanographic Institute, Moscow. The measurements of alkalinity and TIC were performed at NIVA using the techniques described in Dickson et al. 2007. The $\mathrm{pH}$ data were also calculated as a function of alkalinity and TIC with the co2sys tool (Lewis and Wallace, 1998, http://www.ecy.wa.gov/programs/eap/ models.html). The total concentration of metals was measured using the method of atomic absorption with direct electrothermal atomization of samples according to reference documents RD 52.24.377-2008 and RD 52.10.778-2013 developed in Roshydromet [Hydrometeoizdat, 1993 .

\section{Results}

The results of the experiment show that the possible changes in seawater composition are connected to the permafrost thawing.

Figure 2, Figure 3, Figure 4, and Figure 5 demonstrate concentration changes of the chemical parameters examined in this study in 1 liter of the sea water after adding $1 \mathrm{~g}$ of permafrost. The concentration of phosphates increased from 0.36 to $1.36 \mu \mathrm{M}$ during the first 3 hours. After that, it was steadily decreasing until it reached $0.60 \mu \mathrm{M}$ at the 24-hour mark (Figure 2). The concentration of nitrites and nitrates increased from 1.0 to $2.14 \mu \mathrm{M}$ before concentration started to decline after the 3hour mark and reached $1.57 \mu \mathrm{M}$ after 24 hours. A similar trend was seen in silicon: the concentration started at $11.0 \mu \mathrm{M}$ then it reached $61.0 \mu \mathrm{M}$ after 3 hours before decreasing to $29.5 \mu \mathrm{M}$ after 24 hours. Therefore, nutrients show a clear enrichment with a maximum after 3 hours, and the decline of concentrations afterward.

Alkalinity and Total Inorganic Carbon had minimum values in the 3 hours sample then the content increased. It should be pointed out, that the first measurement of the initial seawater was taken without permafrost. The addition of permafrost should have lowered the salinity of the sample, and therefore the TIC content (as one of the main ion) and Alk, as can be seen in Figure 3. After 24 hours Alk and TIC increased and reached concentrations close to the initial ones. Values of $\mathrm{pH}$ decreased from 8.40 to 7.50 after 24 hours (the signal was more clearly seen in the $\mathrm{pH}$ calculated as a function of Alk and TIC than the measured with a pH meter). The concentration of total $\mathrm{Hg}$ in the first sample was minimum and equaled $2.1 \mathrm{ng} / \mathrm{L}$, at 3 -hour (a)

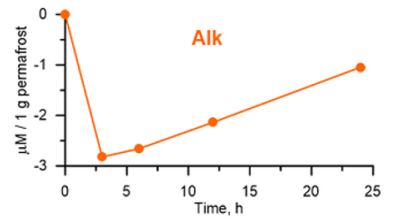

(c)

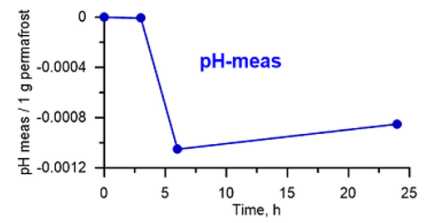

(b)

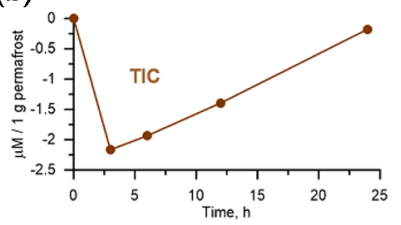

(d)

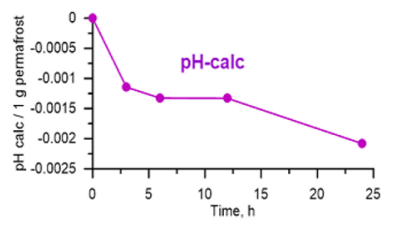

Figure 3. Change of concentrations of Alkalinity (a), Total Inorganic Carbon, TIC (b), pH measured (c) and $\mathrm{pH}$ calculated (d) due to thawing of $1 \mathrm{~g}$ of permafrost in 1 liter of the sea water. 
(a)

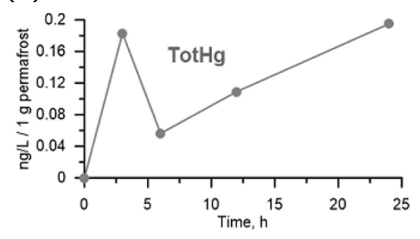

(b)

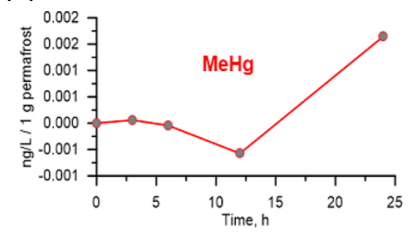

Figure 4. Change of concentrations of total mercury, TotHg (a), methylmercury and $\mathrm{MeHg}$ (b) due to thawing of $1 \mathrm{~g}$ of permafrost in 1 liter of the sea water.

mark it reached $11.6 \mathrm{ng} / \mathrm{L}$, then after decreasing to $5.0 \mathrm{ng} / \mathrm{L}$ it continued to raise up to $12.2 \mathrm{ng} / \mathrm{L}$. $\mathrm{Me}-\mathrm{Hg}$, on the other hand, did not show a clear trend. $\mathrm{Pb}$ reached its maximum of $10 \mathrm{ng} / \mathrm{L}$ after 12 hours; the highest concentration of $\mathrm{Cu}$ was measured at the 3-hour mark however it continued to increase after 6 hours. Ni concentration also reached its maximum in the 3-hour sample and later decreased to $13 \mathrm{ng} / \mathrm{L}$. The highest concentration of $\mathrm{Mn}(2700 \mathrm{ng} / \mathrm{L})$ was measured at the same time as $\mathrm{Ni}$ and $\mathrm{Cu}$; after 24 hours it equaled $660 \mathrm{ng} / \mathrm{L}$; Zn showed its maximum of $80 \mathrm{ng} / \mathrm{L}$ in 12-hour sample, Fe concentration reached a maximum of $81,000 \mathrm{ng} / \mathrm{L}$ at 3-hour mark, Al had two peaks at $3(8900 \mathrm{ng} / \mathrm{L})$ and $12(9800 \mathrm{ng} / \mathrm{L})$ hours and it decreased to $6500 \mathrm{ng} / \mathrm{L}$ at the end of the experiment. Consequently, concentrations of the total metals generally increased during the experiment with the exception of cadmium, which concentration was below the detection limit in all samples.

\section{Discussion}

The way permafrost thawing affects the Arctic ecosystem is currently an understudied field that requires attention. The effects are currently not included in global climate models as parameterization is difficult because of lack of process-based understanding. New experiments, like the one presented in this study that improve our understanding of the biogeochemical and carbonate system parameters, as well as metals, are therefore, very important. The data on the content of metals in permafrost are very rare, although the data from previous experiments exist on nutrients which can be compared to our results. (a)

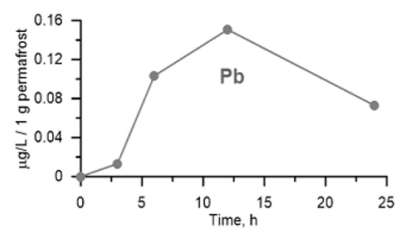

(c)

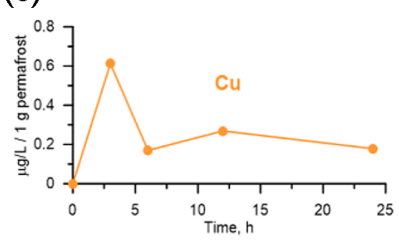

(e)

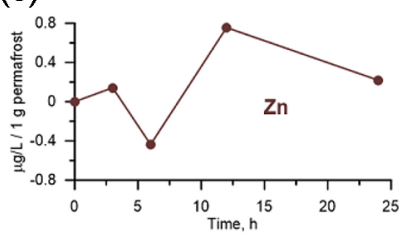

(g)

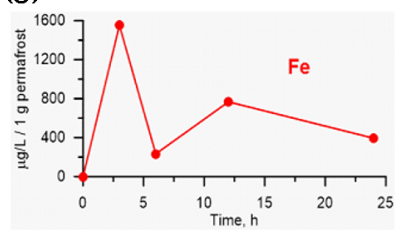

(b)

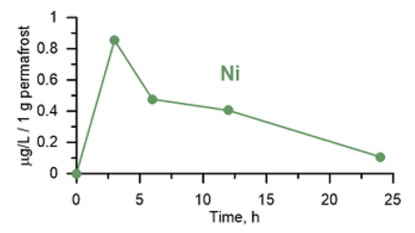

(d)

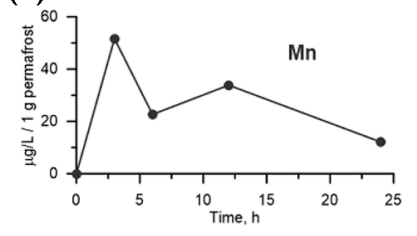

(f)

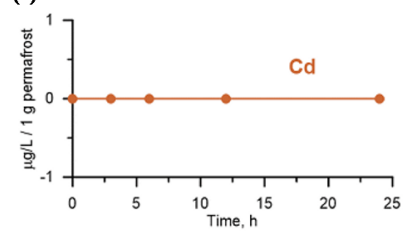

(h)

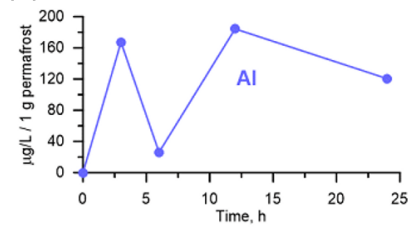

Figure 5. Change of concentrations of lead, $\mathrm{Pb}$ (a), nickel, Ni (b), copper, $\mathrm{Cu}$ (c), manganese, $\mathrm{Mn}$ (d), zinc, Zn (e), cadmium, Cd (f), iron, Fe (g), aluminum, $\mathrm{Al}(\mathrm{h})$ due to thawing of $1 \mathrm{~g}$ of permafrost in 1 liter of the sea water.

For nutrients, our experiment showed the maximum rates of release from $1 \mathrm{~g}$ of permafrost during the 1st 3 hours of phosphate $0.16 \mu \mathrm{mol} \quad \mathrm{P} \quad \mathrm{g} \quad \mathrm{WW}^{-1} \quad \mathrm{~d}^{-1}$, nitrate $0.16 \mu \mathrm{mol} \quad \mathrm{N} \quad \mathrm{g} \quad \mathrm{WW}^{-1} \quad \mathrm{~d}^{-1}$ and silica $8 \mu \mathrm{mol} \mathrm{Si} \mathrm{g} \mathrm{WW}{ }^{-1} \mathrm{~d}^{-1}$. During our experiment, we did not measure carbon directly, but the Redfield based calculations can provide the rate of carbon release from 1 to $10 \mu \mathrm{mol} \mathrm{C} \mathrm{g} \mathrm{WW} \mathrm{WW}^{-1}$.

Degradation rates of marine sediments in the Laptev and the East Siberian seas were studied by [Karlsson et al., 2015 who found that the incubated-based anaerobic degradation rate differs by 6 times from $2.4 \mu \mathrm{mol} \mathrm{CO} \mathrm{g} \mathrm{OC}^{-1} \mathrm{~d}^{-1}$ in the Laptev Sea to $15 \mu \mathrm{mol} \mathrm{CO}_{2} \mathrm{~g} \mathrm{OC}^{-1} \mathrm{~d}^{-1}$ in the East Siberian Sea, and aerobic degradation estimated in the East Siberian Sea was about $30 \mu \mathrm{mol} \mathrm{CO}_{2} \mathrm{~g} \quad \mathrm{OC}^{-1} \mathrm{~d}^{-1}$. This aer- 
Table 2. Comparison of an Increase in Concentrations due to Permafrost Thawing, Supply From the Rivers and Atmospheric Deposition of Phosphate, Nitrate and Silicate

\begin{tabular}{|c|c|c|c|}
\hline Parameter & $\mathrm{PO}_{4}$ & $\mathrm{NO}_{X}$ & $\mathrm{Si}$ \\
\hline $\begin{array}{l}\text { Content of parameter per } 1 \mathrm{~g} \text { of } \mathrm{PF} \text {, estimated by an } \\
\text { increase of concentrations in the seawater, } \mathrm{g} / \mathrm{g} \mathrm{WW}\end{array}$ & $6 \times 10^{-7}$ & $3 \times 10^{-7}$ & $2.7 \times 10^{-5}$ \\
\hline Amount of parameter released from thawing of & & & \\
\hline $20 \mathrm{mln} \mathrm{t} / \mathrm{yr}$ of Arctic PF [Vonk et al., 2012], $10^{3} \mathrm{t} \mathrm{yr}^{-1}$ & 0.001 & 0.006 & 0.053 \\
\hline Supply with rivers [Holmes et al., 2012], $10^{3}{\mathrm{t} \mathrm{yr}^{-1}}^{-1}$ & 39 & 182 & 6062 \\
\hline 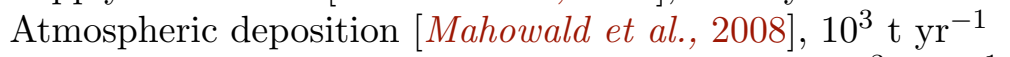 & 2.2 & & \\
\hline Atmospheric deposition [Kanakidou et al., $\overrightarrow{2016}], 10^{3} \mathrm{t} \mathrm{yr}^{-1}$ & & 140 & \\
\hline
\end{tabular}

obic degradation rate with a correction of organic carbon content $\left(10 \mathrm{mg}\right.$ OC $\left.\mathrm{g} \quad \mathrm{DW}^{-1}\right)$ can give $0.3 \mu \mathrm{mol} \quad \mathrm{CO}_{2} \mathrm{~g} \quad \mathrm{DW}^{-1} \quad \mathrm{~d}^{-1}$ or $0.15 \mu \mathrm{mol} \mathrm{CO} \mathrm{g} \mathrm{WW}^{-1} \mathrm{~d}^{-1}$ (for porosity $50 \%$ ).

Therefore, the degradation rates of permafrost estimated in this study can be in 1-2 orders of magnitude higher than the aerobic degradation rate of the sediments that seems to be reasonable.

The data of this experiment allowed us to estimate the total annual supply of nutrients to the Arctic from permafrost thawing by multiplying the change in concentration from this study by the annual eroded permafrost total volume in Siberia [Vonk et al., 2012].

Our results indicate that the total amount of nutrients originated from the permafrost thawing of the abrasive cliffs (i.e. $0.001 \times 10^{3} \mathrm{t} \mathrm{yr}^{-1}$ for

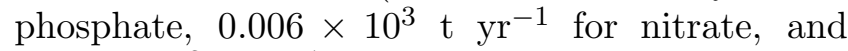
$0.053 \times 10^{3} \mathrm{t} \mathrm{yr}^{-1}$ for silicate) is very small compared to the other sources. i.e. rivers and atmospheric deposition Table 2). According to [Holmes et al., 2012 an annual flux with rivers taken into account equals $39 \times 10^{3} \mathrm{t} \mathrm{yr}^{-1}$ for phosphate, $182 \times 10^{3} \mathrm{t} \mathrm{yr}^{-1}$ for nitrate, and $6062 \times 10^{3} \mathrm{t} \mathrm{yr}^{-1}$ for silicate. Phosphate atmospheric deposition in the Arctic Ocean was estimated by [Mahowald et al., 2008 as $2.2 \mathrm{Gg} \mathrm{P} / \mathrm{yr}\left(2.2 \times 10^{3} \mathrm{t} \mathrm{yr}^{-1}\right)$. Atmospheric deposition of $\mathrm{NO}_{X}$ can be calculated using model estimates by [Kanakidou et al., 2016] of deposition flux of $10 \mathrm{mg} \mathrm{N} \mathrm{m}^{-2} \mathrm{t} \mathrm{yr}^{-1}$, that can be yielded for all the Arctic region $\left(14,056,000 \mathrm{~km}^{2}\right.$, https://en.wikipedia.org/wiki/Arctic_Ocean) approximately as $140 \times 10^{3} \mathrm{t} \mathrm{yr}^{-1}$.

Table 2 shows that the permafrost thawing origin supply of phosphate is 4 orders of magnitude lower than the atmospheric deposition and 5 orders of magnitude lower than what is supplied from the rivers. For nitrate and silicate, permafrost release is about 6 orders of magnitude lower than those due to the presence of rivers and the atmosphere. With that in mind, the permafrost nutrients originating from the erosion probably have a very limited effect on the overall biogeochemical system of the Arctic Ocean; but can have a stronger influence on the coastal ecosystems. The effect of the decreasing $\mathrm{pH}$ caused by the coastal abrasion was clearly detected in the analyzed samples; but its influence on the overall Arctic is difficult to upscale.

\section{Conclusions}

This study has shown the results of a microcosm experiment where the goal was to increase our understanding of the immediate permafrost thawing effects on seawater. The chemical effects were observed and measured frequently over the first 24 hours after thawing to quantify the effects on the overall chemical composition of the seawater. The results suggest that the effects of permafrost coastal abrasion on the seawater nutrient composition can be locally important but are much less significant when compared with other sources of nutrients in the Arctic such as rivers.

Acknowledgments. This research was performed in the framework of the state assignment of FASO Russia (theme No. 0149-2018-0035) with an additional support from The Research Council of Norway - projects 246752 "POMPA-Pollutants and Carbonate System Parameters in Polar Environmental Media: Snow-Ice-SeawaterSediments-Coastal Discharge", 283482 "ICOTA - Influence of coastal permafrost thawing on biogeochemistry 
and pollutants of the sea water", Svalbardsmiljøvernfond project "Permafrost decay for acidification/bioproductivity", Norwegian Ministry of Climate and Environment projects PERMACID and ARCRISK and Russian State Hydrometeorological Survey Science Project (NIOKR 1.5.3.7).

\section{References}

AMAP (2017), Snow, Water, Ice and Permafrost in the Arctic (SWIPA) 2017. Arctic Monitoring and Assessment Programme, 269 pp. AMAP, Oslo, Norway.

Braaten, H. F. V., H. A. de Wit, C. Harman, et al. (2014), Effects of sample preservation and storage on mercury speciation in natural stream water, International Journal of Environmental Analytical Chemistry, 94, 381-384, Crossref

Dickson, A. G., C. L. Sabine, J. R. Christian (2007), Guide to Best Practices for the Ocean CO 5152 Measurements, PICES Special Publication, 3, 191.

IPCC (2014), Climate Change 2014: Synthesis Report. Contribution of Working Groups I, II and III to the Fifth Assessment Report of the Intergovernmental Panel on Climate Change (Core Writing Team, R. K. Pachauri and L. A. Meyer, eds.), 151 pp. IPCC, Geneva, Switzerland.

Grashoff, K., K. Kremling, M. Ehrhard (1999), Methods of Seawater Analysis, 3rd completely revised and extended edition, $632 \mathrm{pp}$. WILEY-VCH Verlag GmbH, Weinheim-New York-Chichester-BrisbaneSingapore-Toronto. Crossref

Holmes, R. M., J. W. McClelland, et al. (2012), Seasonal and annual fluxes of nutrients and organic matter from large rivers to the Arctic Ocean and sur- rounding seas, Estuaries and Coasts, 35, No. 2, 369-382, Crossref

Hydrometeoizdat (1993), Rukovodstvo po Khimicheskomu Analizu Morskikh Vod, 129 pp. Hydrometeoizdat, St. Petersburg. (in Russian)

Kanakidou, M., et al. (2016), Past, present, and future atmospheric nitrogen deposition, Journal of the Atmospheric Sciences, 73, No. 5, 2039-2047, Crossref

Karlsson, J., A.-K. Bergstrom, P. Bystrom, et al. (2015), Terrestrial organic matter input suppresses biomass production in lake ecosystems, Ecology, 96, 2870-2876, Crossref

Mahowald, N., et al. (2008), Global distribution of atmospheric phosphorus sources, concentrations and deposition rates, and anthropogenic impacts, Global Biogeochemical Cycles, 22, No. 4, 1-19, Crossref

Semiletov, I., et al. (2013), Space-time dynamics of carbon and environmental parameters related to carbon dioxide emissions in the Buor-Khaya Bay and adjacent part of the Laptev Sea, Biogeosciences, 10, 5977-5996.

Vonk, J. E., et al. (2012), Activation of old carbon by erosion of coastal and subsea permafrost in Arctic Siberia, Nature, 489, No. 7414, 137-40, Crossref

H.-F. Braaten, T. Kristiansen and E. Yakushev, Norwegian Institute for Water Research, Gaustadalléen 21, 0349 Oslo, Norway. (trond.kristiansen@niva.no;

HansFredrik.VeitebergBraaten@niva.no; evgeniy.yakushev@niva.no)

A. Ilinskaya and A. Polukhin, Shirshov Institute of Oceanolgy RAS, Nakhimov Avenue 36, 117997 Moscow, Russia.(ilinskaya.alice@gmail.com; aleanapol@gmail.com)

M. Pogojeva, State Oceanographic Institute, Kropotkinsky line 6, 119034 Moscow, Russia.

(pogojeva_maria@mail.ru) 